\title{
Anal Cancer pT3 TNM Finding v6 and v7
}

National Cancer Institute

\section{Source}

National Cancer Institute. Anal Cancer pT3 TNM Finding v6 and v7. NCI Thesaurus. Code C67541.

Anal cancer with tumor size more than 5 centimeters in greatest dimension. (from AJCC 6th and 7th Eds.) 